NEW YORK UNIVERSITY

STERN SCHOOL OF BUSINESS

FINANCE DEPARTMENT

Working Paper Series, 1995

Rethinking Emerging Markets.

Smith, Roy C., and Ingo Walter.

FIN-95-32 



\title{
Rethinking Emerging Markets
}

\author{
by Roy C. Smith and Ingo Walter
}

The Mexican financial crisis of late 1994 and early 1995 resulted in a linked collapse of stock market values in almost all developing countries, regardless of economic policies or performance. The contagion effect was clear, and much commented on, if not fully explainable by either theory or past experience. Other Latin American equity markets, being close to ground zero, universally declined by $15 \%$ to $30 \%$ in less than a month. So did markets in Asia, where price indexes in Hong Kong, Singapore, Taipei, Seoul and Bangkok dropped $10 \%$ to $15 \%$ in a matter of days. Markets in Poland, Hungary and the Czech Republic were off by similar amounts.

These dramatic price declines in the so-called "emerging market" countries occurred against the backdrop of ongoing declines in share prices. ${ }^{1}$ And, together with sizeable losses in emerging market bonds, savaged the investment performance of sophisticated hedge funds, country funds and regional funds that had made major commitments to emerging equity markets. In turn, they triggered sharp portfolio adjustments and mutual fund redemptions, and caused a general loss of confidence in developing-country stock markets as serious investment vehicles.

Observers with long memories and students of economic history saw in these

\footnotetext{
'The Morgan Stanley Group Emerging Market Index dropped nearly 20\% in calendar 1994, having risen by $20 \%$ in 1993 , and $48 \%$ in 1992 . Stock prices in individual countries that had attracted particularly large portfolio equity inflows were hit much harder than the index as a whole. As measured in dollar terms at the end of January 1995, as compared to January 1, 1994, the stock market in Turkey was down $57 \%$, Mexico $56 \%$, China $54 \%$, Poland $50 \%$, Hong Kong $41 \%$, Israel $40 \%$, and $10 \%$ or more in just about all the rest of the emerging market countries. The principal exceptions were Chile where the market was up $42 \%$, Brazil $39 \%$, South Africa $10 \%$ and South Korea $9 \%$ over the same period.
} 
developments clear echoes of the past. Developing country bond market collapses-mainly sovereign debt defaults by government issuers-occurred repeatedly in the 1820s, the 1870s, and the 1930s (see Exhibit 1), visiting repeated, massive losses on foreign investors but spaced widely enough apart to convince investors that past performance was not a good guide to current conditions. ${ }^{2}$ Still, international bond markets remained skeptical when the great developing country borrowing boom occurred in the 1970s, which consequently involved almost exclusive reliance on the market for syndicated bank loans and eventually visited large losses on the lending banks after the Mexican crisis of 1982 . The 1980s saw dreary cycles of massive loan reschedulings, new-money packages, maturity stretch-outs and forced lending, and the end of the crisis was heralded by Brady Plan bonds-for-loans conversions - in turn setting the stage for the emerging markets securities boom of the early 1990 s. What goes around, comes around.

Indeed, the emerging market investment phenomenon of the early 1990s was partly a bubble-the result of a global investment stampede in which aggressive institutions and mutual funds competed to buy up a relatively small supply of securities. The strong demand induced an increase in that supply, as new securities were issued through secondary offerings by public companies and initial public offerings, privatizations of state-owned enterprises, and financings of new projects. During the four-year period to the end of 1994 , approximately $\$ 500$ billion of new

\footnotetext{
${ }^{2}$ For an excellent review of the history of developing country debt defaults and reschedulings, see Salomon Brothers, Emerging Market Borrowing: Lessons from History (New York: Salomon Brothers Inc., 1993).
} 
○̊

o

¿ 尺 웅
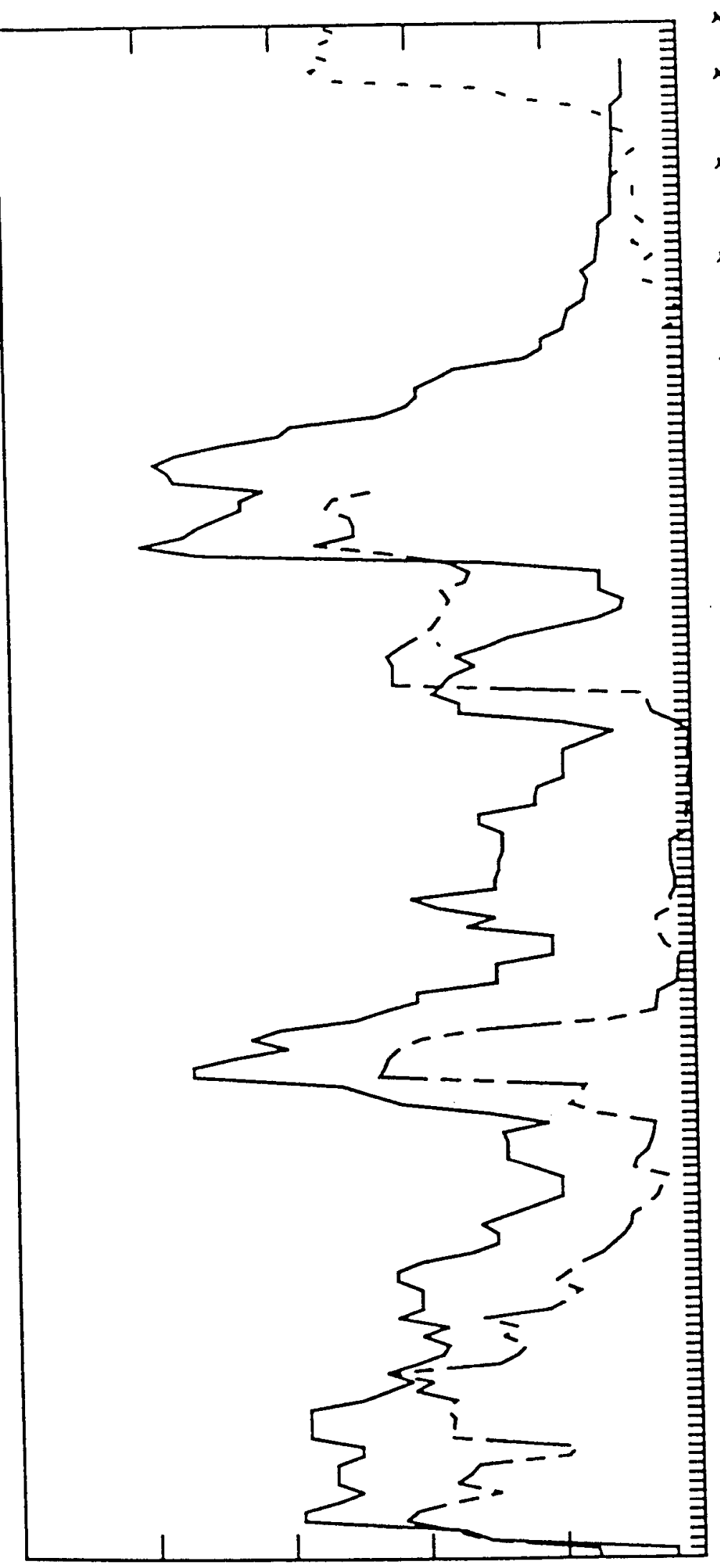

مீ $\begin{array}{lllll}0 & 0 & 0\end{array}$
$\stackrel{Ð}{\Xi}$

몽

के 잉

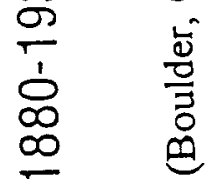

$195^{3}$

$\mathrm{ag}^{3}$

$9^{3^{3}}$

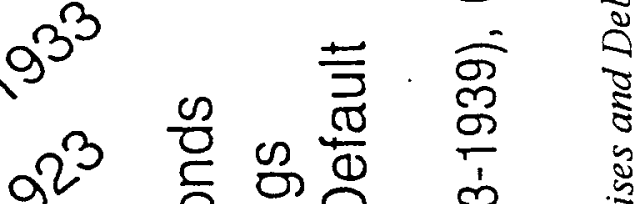

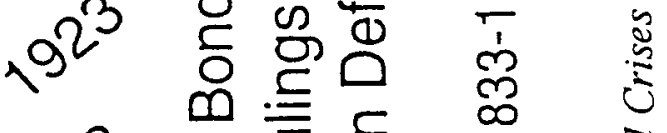

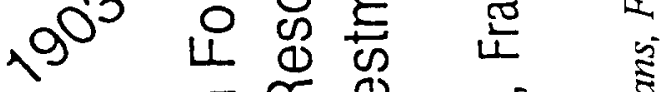

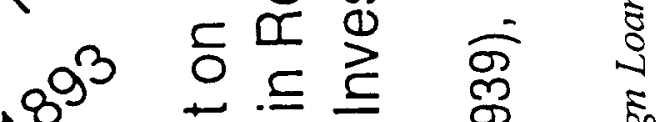

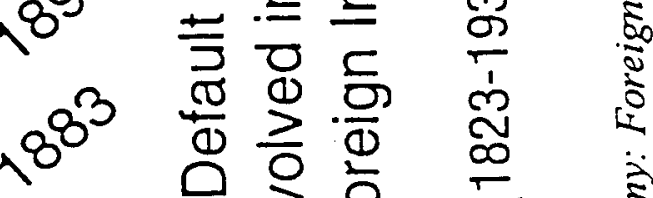

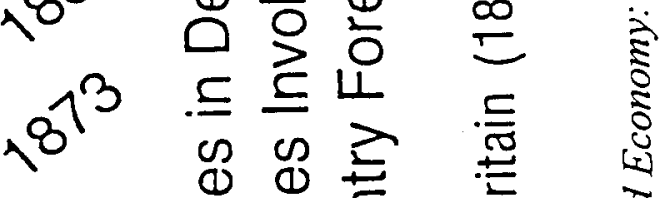

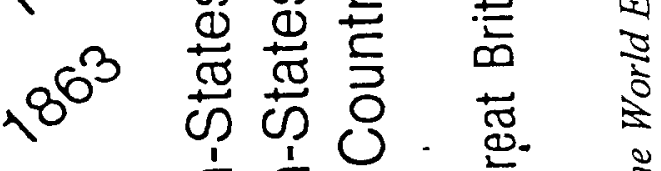

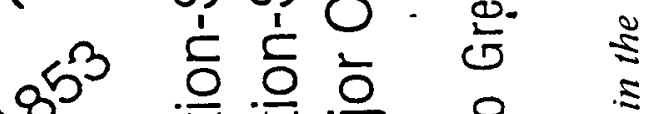

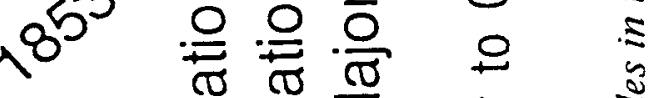

${ }_{1} x^{3} \sum_{i}^{\pi} \sum_{i}^{\frac{\pi}{\omega}}$

$18^{3^{3}}$

$18^{23}$

5

\&

$\equiv \widehat{\sigma}$

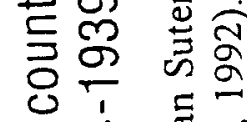

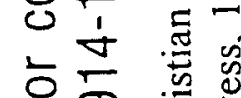

음효

$\sum$ 里

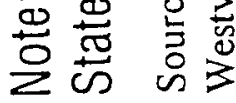


foreign money poured into fewer than 30 developing countries. ${ }^{3}$ Of this total, approximately $20 \%$ was in the form of portfolio investments in stocks, which at that point had a combined market value of about $\$ 200$ billion despite the discouraging market results during 1994 due to substantial profit-taking and a sharp curtailment of new investment inflows. In 1994, stock and bond purchases and foreign direct investment in all emerging market countries combined totaled $\$ 175$ billion as against $\$ 40$ billion in 1990 - of which less than $\$ 2$ billion represented stock purchases. ${ }^{4}$ See Exhibit 2.

These developments raise three important questions of interest to international investors and governments of emerging market countries alike, which we address in this article: (1) What caused the investment surge to begin, and to end? (2) Does this mean a longer-term erosion of investor interest in emerging markets? (3) If so, what are the implications for the new and widely cheered thinking about economic development being the just reward for drastic policy changes towards free markets and sound money, thinking that today is referred to as the "Washington Consensus?" 5 The answers are of fundamental importance to the economic development process, and to the process of global capital allocation.

In this paper, we take the view that the emerging market investment boom was

${ }^{3}$ International Finance Corporation.

${ }^{4}$ World Bank data, from The Economist Jan 28, 1995, and Financial Times, Feb. 20, 1995.

${ }^{6} \mathrm{~A}$ term coined by John Williamson of the Institute for International Economics as the forventional wisdom among opinion-leaders that free markets and price stability are preconditions for viable economic development, comprising such elements as removal of internal and external enterprises. 


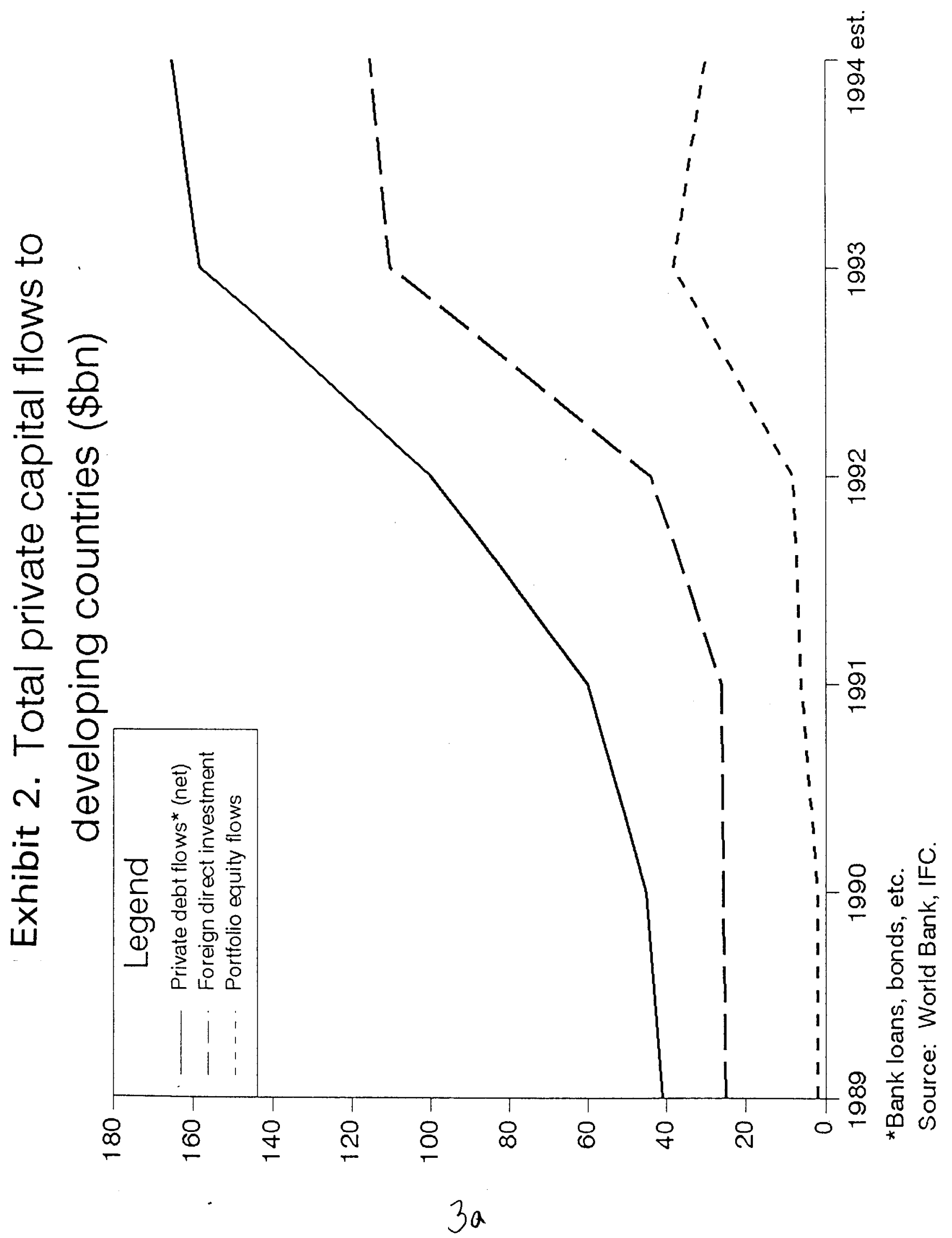


not so much ill founded as it was excessive. As Paul Krugman has pointed out, ${ }^{6}$ the surge of investments into these markets had many characteristics of a tulip bulb mania, that is, the prices got out of line with reality. Now the market has had its reality check and will not behave foolishly again. Capital flows to emerging market countries will continue but these will have to be earned, not only by the continuation of determined policies intended to expedite market economies, but also in competition with other countries seeking to do the same. This is a process of succeeding in a competitive environment, something that many developing countries have not been overly concerned about in the past. The recent surge on money flows into these countries, and out again, has left behind some lessons which those countries intent on real economic progress in the future will have to master.

\section{Behind the Surge}

The end of the 1980s saw a collapse in the market for high-performance investment vehicles such as leveraged buyouts, takeovers financed with junk bonds, speculative real estate development in North America, Japan and Europe, as well as Japanese stocks, a market which had enjoyed nearly twenty years of continuously rising prices. Institutions had been the principal investors in these instruments which, having served their time, needed to be replaced.

Despite the difficulties of the late 1980s, financial markets looked ahead optimistically to a vast expansion of activities as a result of the considerable

\footnotetext{
" Dutch Tulips and Emerging Markets," Foreign Affairs, July/August 1995.
} 
deregulation in Western Europe following efforts to implement the EU's single market initiative, the rebirth of Eastern Europe as a collection of nascent market-driven economies, and the recognition that liberalizing reforms in countries like Chile and Mexico could bring to Latin America much of the potential realized in the marketoriented economies of Asia. Indeed, in the gloomy recession-bound times of the early 1990s in New York, London and Tokyo, the lure of the emerging markets of Latin America and Asia became self-evident. Attention was attracted away from the conventional international investments of the past to converge upon the promise of undervalued, high-growth and diversification opportunities in parts of the world that had not materially participated in international portfolio investment before.

\section{Emerging Markets Emerge}

The first equity markets to "emerge" during the 1980 s were actually France, Germany, Spain and Italy-all countries in which capital market instruments appeared in some quantity for the first time following deregulation efforts and market reforms during that decade. After the fall of the Berlin Wall in 1989, the excitement shifted to Eastern Europe, where investment opportunities were pursued aggressively, especially in Poland, the Czech Republic and Hungary, although such investments were severely constrained by a shortage of securities. Country-specific investment funds such as the Morgan Stanley Germany Fund, which was intended to identify choice investments in the newly unified Germany, quickly rose in the market to trade at substantial premiums above their net asset values.

Also during this time, the major international banks were unwinding the last of 
their Latin American loans (and some in otger parts of the world) which had been in arrears for many years. Some were able to sell their loans at deep discounts in the secondary market to market-makers who would resell them to others. The Brady Plan (1989) created a new supply of debt instruments for loan-conversion-about $\$ 250$ billion at par value-which were collateralized as to principal by U.S. government securities and offered partial interest payment guarantees. These soon became actively traded as a new form of low grade, high-yield bond, offering equity-like returns to investors. Bond yields of $25 \%$ to $40 \%$ were available on many Latin American issues, rates which continued to reflect bank loan losses that many investors felt should not apply to the post-Brady situation. The Brady restructurings were coupled to government promises of immediate and significant regulatory reforms and improved economic management. The first country subject to Brady debt restructuring was Mexico under President Carlos Salinas de Gortari, soon followed by Argentina, where the new government of Carlos Menem, a former radical Peronista, had aggressively pursued market economics and privatization.

Early success with Brady bonds, recognition of beneficial effects of serious economic policy reforms, evidence of substantial foreign direct investment by multinational corporations, and the return of massive amounts of flight capital by residents of Mexico, Argentina and other Latin American nations began to be reflected in the stock markets of those countries. Private capital flows to major Latin American countries exceeded $\$ 72$ billion in 1993, a substantial turnaround from the late 1980 s when capital flows were negative, as shown in Exhibit 3. This activity attracted U.S., 


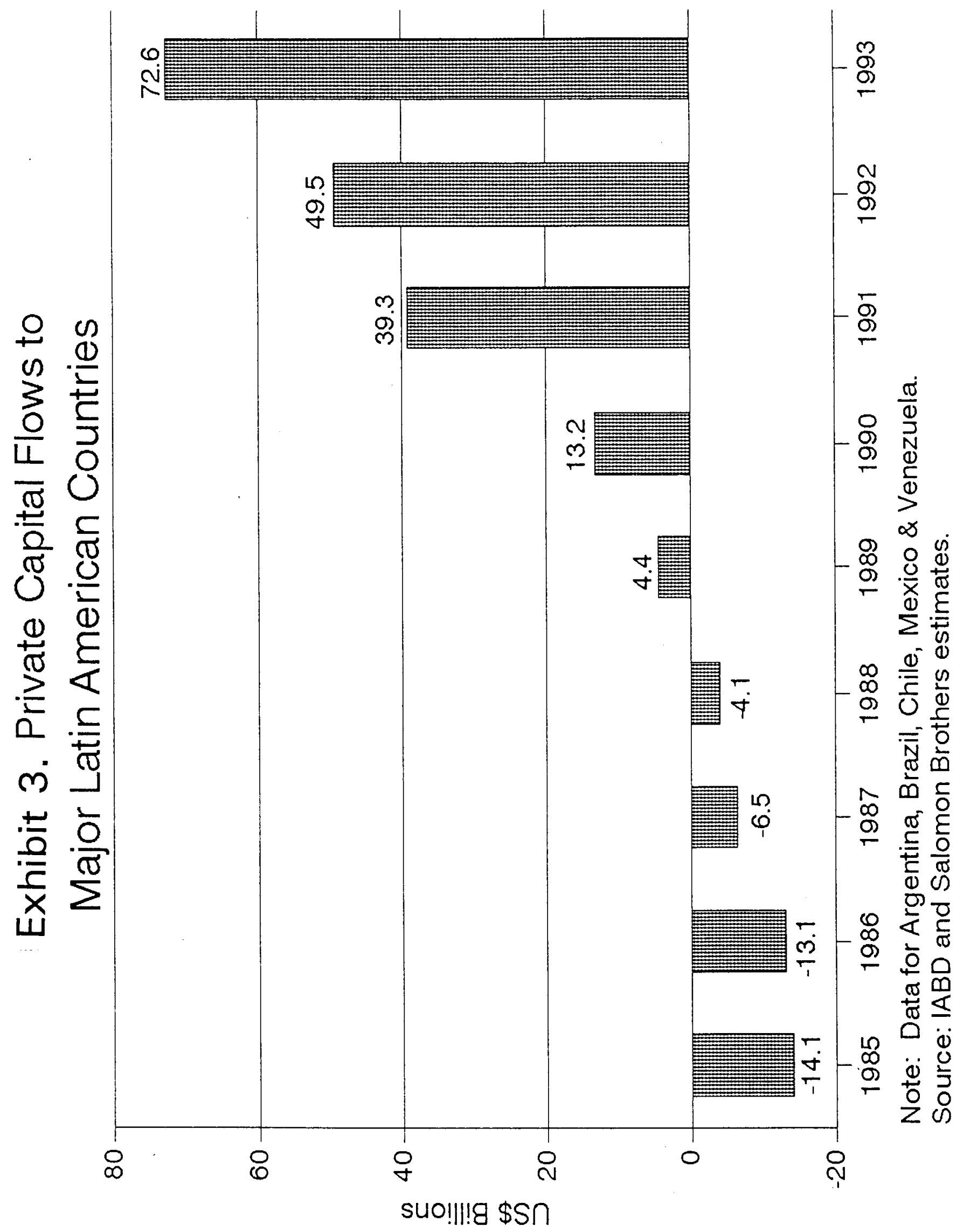

$6 a$ 
British and other fund managers, who began to invest aggressively, and the sudden flow of funds into comparatively illiquid markets began to demonstrate the expected price effects. Stock prices rose rapidly, encouraging investment bankers and money managers to augment their offerings of emerging market funds to smaller institutions and to the general public. As of June 30, 1993 the 100 largest among such funds had an aggregate net asset value of $\$ 26.3$ billion. By the end of that year, the combined net asset value of these funds had more than doubled to $\$ 54.1$ billion as a result of both market appreciation and new money raised. ${ }^{7}$ It was not so much the availability of attractive investment returns that caused the capital stampede. These had been available before. Rather, it was the changed perception of these countries from backward, hopeless places in which money could only be made by those on the inside, to bright beacons of hope for revival based on the long delayed discovery of economic truth. This was not just the reading of the situation by the Washington consensus, it was a view shared by those with serious money in New York, London, Zurich and Tokyo.

\section{The Apparent Wisdom of Putting Eggs in Different Baskets}

A popular explanation offered by emerging market investors to explain their aggressive involvement in emerging markets was the idea that corporate assets were available very cheaply in some countries relative to the value of comparable assets in the U.S. or other developed-country markets, because the political and economic risks

\footnotetext{
7"World's 100 Largest Emerging Market Equity Funds،" Micropal, April 1994.
} 
were so high. But what if the risks were to decrease dramatically because of sensible economic practices along the lines of the Washington Consensus? Argentina was often used as an example: Once the government's new economic policies were known and appeared to be both credible and durable, the Buenos Aires stock market shot up to correct the undervaluation of the corporate assets for the new environment embodying dramatically lower perceived risk. Thus investors' search should not only be for potentially attractive companies, but also for countries whose economic policies were about to change. Early investments in Peru, Turkey, Poland and China were made on this basis. An associate of George Soros noted that they liked to invest when things have gone from utterly hopeless to just plain desperate. "Peru has come back to the world," he said." It had dug itself out of "an economic mess second to none," and was now a suitable place to invest. ${ }^{8}$

Modern investment concepts also contributed to the surge of capital allocation to emerging market equities. Everyone knows that prudent investors don't put all their eggs in one basket. Here was a whole new set of baskets that promised not only high returns but also great potential for investment diversification.

A so-called "optimum portfolio" is one that minimizes the risk embedded in a collection of assets for a particular target rate of return, or maximizes total investment returns for a desired level of risk - with risk defined as the variability of the total return of the portfolio as a whole. Within this framework, the optimum portfolio selected by an investor depends on his or her risk preference. The attractiveness of adding any

\footnotetext{
${ }^{8}$ Mary Powers "Soros Fund Manager Says Peru has Turned Around," Reuters Asia-Pacific Report, July 23, 1993.
} 
individual asset or group of assets-cash, gold, stocks, bonds, real estate, etc. - to that portfolio depends on the expected total returns on that asset and what impact it has on the risk of the overall portfolio. The less correlated the returns of a given asset are with the other assets already in the portfolio, the greater the benefits from diversification and therefore the less risky is the overall portfolio.

For investors large and small in the early 1990s, emerging markets appeared to offer investors extraordinary benefits in this regard. Not only did they expect their overall returns to be very high-fundamentally a product of extraordinarily high expected real growth rates associated with new, internationally acclaimed economic policies in many emerging market countries-but the international portfolio diversification (IPD) benefits were seen to be extraordinarily high as well, due to evidence of relatively low correlations between emerging market stock returns and the major market indexes such as the Standard \& Poors 500 index, the French CAC40 or the German DAX equity averages.

Exhibit 4 shows this pattern using a so-called "efficient frontier" mapping risks and returns for different equity portfolio allocations between $100 \%$ major-market and $100 \%$ emerging-market asset allocations. ${ }^{9}$ During the $1987-94$ period, U.S. dollarbased investors could achieve both lower risk and higher returns (a financial "free lunch") by deploying a significant portion of their stock investments in emerging markets. According to Exhibit 4, for the same level of investment risk as in a portfolio

\footnotetext{
${ }^{8}$ "Major market" in this case is defined as the U.S. dollar-based Morgan Stanley Capital International World Index, while "emerging market" is defined as the U.S. dollar-based International Finance Corporation Emerging Markets Composite Index, each weighted by the capitalizations of the various markets.
} 


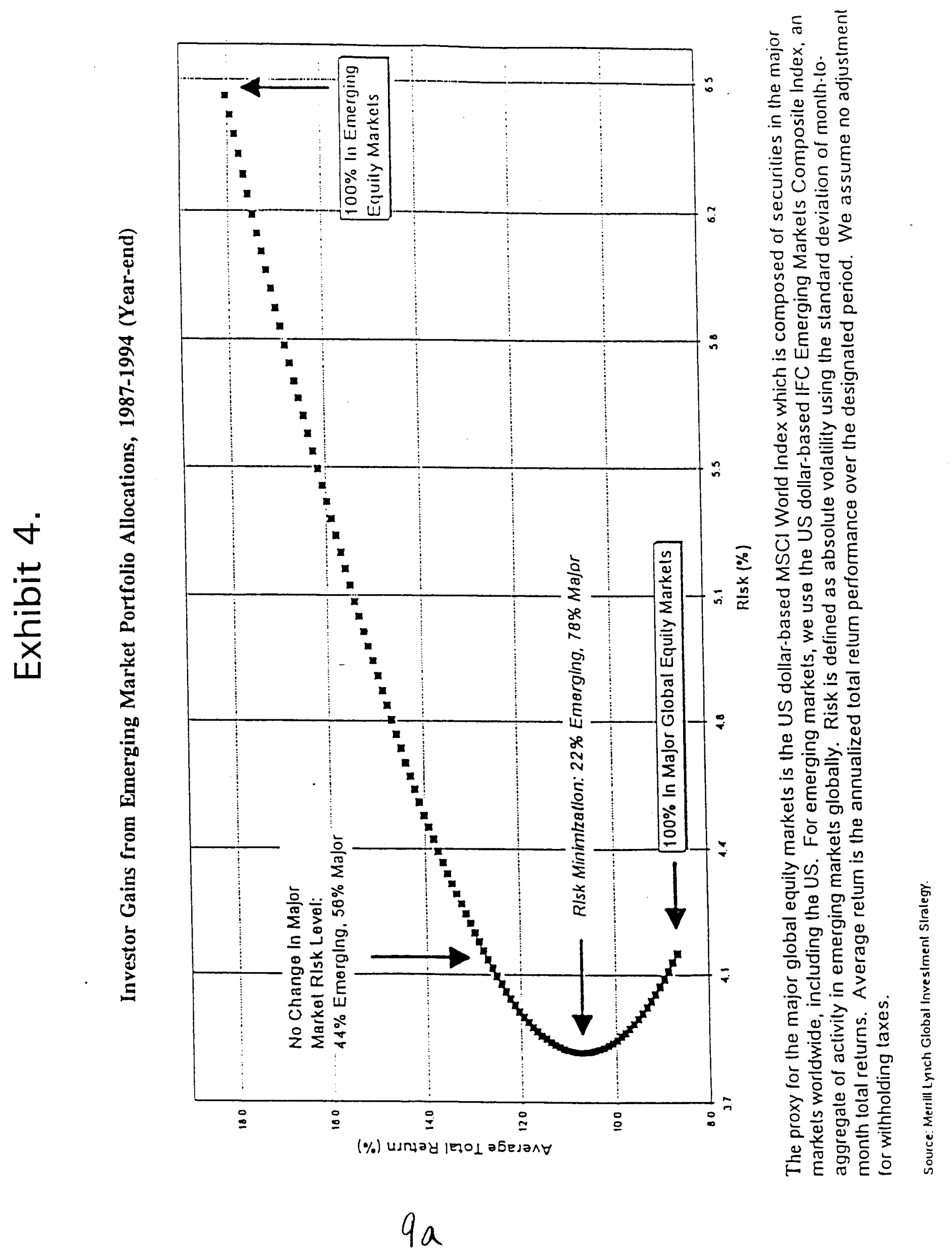


without emerging market securities-i.e., invested $100 \%$ in major markets, which returned about $9 \%$ - a higher return of about $13 \%$ was possible with an allocation of $44 \%$ of the portfolio into emerging market stocks. Similarly, if the object was to minimize risk, a portfolio consisting of $22 \%$ emerging market securities produced a return of about $11 \%$, far higher than the $8.5 \%$ return on the $100 \%$ major market portfolio, and at substantially lower risk. The IPD gains are attributable both to less than perfectly correlated movements in stock market indexes between major and emerging markets as well as less than perfectly correlated exchange rate movements against the dollar-ensuring "different baskets" for the investor's eggs. ${ }^{10}$

The data certainly looked good, but how reliable were they? Many of the more popular emerging markets had only a few years of history-most of which had been during a global speculative boom. In such markets, statistical information provided by governments and by corporations is often late or unreliable, or both. Net returns require subtracting from gross returns transaction costs (bid-offer spreads, fees, commissions, custody charges, clearance and settlement costs and delays, etc.), which in emerging market countries are often enormous in comparison to the more developed markets. And large risk adjustments are required for market illiquidity, where even moderate buying of selling pressure often leads to massive price changes. Such conditions were certainly far removed from what many investors were used

\footnotetext{
${ }^{10}$ IPD gains tend to be greater across global equity markets than across global bond markets, where they derive solely from less than perfectly correlated interest rate and exchange rate movements. Moreover, unlike the global bond markets, stocks are highly differentiated and subject to local trading conditions, although listings on foreign stock exchanges through depository receipts have made some emerging market equities considerably more accessible to foreign investors.
} 
to-adequate and timely information disclosure and dissemination, low transactions

costs and liquid markets - "details" often overlooked by investors anxious to establish positions before prices ran away from them, and not exactly emphasized by salesmen anxious to earn large fees and commissions. ${ }^{11}$

\section{Privatizations}

The buoyant demand for emerging market securities encouraged countries that were undecided about the free market policies to get on the bandwagon. The obviously positive market-effects of the new policies were a testimony, many felt, to their wisdom.

Rising equity prices made possible many important privatization issues. New issues by emerging market countries, principally privatizations, reached $\$ 17.5$ billion in 1994 , about $\$ 2$ billion more than the year before. These included nearly $\$ 3$ billion in Peruvian, $\$ 2$ billion in Chinese, and over $\$ 1$ billion each in Pakistani and Indonesian privatization issues. Argentina issued $\$ 900$ million of privatization equities in 1994 ,

\footnotetext{
${ }^{1}$ Nor was it much easier to assess investment parameters in emerging debt markets, comprising bond issues by sovereign governments and corporations and sold to international investors. These securities, being rated below investment grade by the principal rating agencies, were looked upon as "junk bonds." International investors usually evaluate junk bond opportunities by comparing the price of the bonds to the risk-free rate of interest for the credit involved. This means adding the default loss rate (i.e., default rate adjusted for recoveries) for foreign bonds to the risk-free rate (e.g., U.S. Treasuries of comparable maturities), so that a dollar bond issued by the government of the Philippines, for example, might be priced at $2 \frac{1}{2} \%$ over comparable U.S. Treasuries to compensate the investor for the higher default risk-commonly called a "haircut." In the case of emerging-market corporate bonds, very little default rate data existed. Instead, investors would look at the country's prevailing sovereign bond yields and would add to it a default rate expectation based on the corporate credit risk involved, a sort of "crew cut" against the risk-free rate.
} 
bringing total proceeds since 1992 to more than $\$ 11$ billion. ${ }^{12}$ Such activity was vastly in excess of any prior usage level of capital markets on the part of these countries. Indeed, by historical standards these amounts were astonishing.

\section{The End of Emerging Market Equities?}

The period from 1990 through 1994 could therefore be characterized as one in which global investors, commanding enormous resources, discovered a limited supply of securities in risky countries that, because of expected economic reforms, appeared to offer exceptional opportunities for price appreciation in the short run, and for growth and further development over the long run, together with extraordinary IPD benefits. The rush to buy pushed emerging market share prices higher, attracting even more investors. Share prices in many markets were bid to levels that considerably exceeded reasonable estimates of risk-adjusted returns.

\section{Speculative Excesses}

As expected, salesmen of emerging market mutual funds aggressively promoted these investments to individuals and institutions in the United States and other developed countries, touting their performance and IPD benefits. Successful sales efforts rapidly expanded investable assets of these funds, which then had to be deployed according to the portfolio weights indicated in the sales materials. As new funds poured in, the underlying equities had to be purchased, further increasing

\footnotetext{
12 "Sales Climb to All-Time Record in 1994," Privatization International, January 1995.
} 
demand for them. Market valuation levels surged further.

Such periods of speculative excess usually do not last more than a few years before something happens that causes investors to rush for the exits. LBOs, junk bond-financed takeovers, biotech stocks, Japanese equity warrants and U.S. mortgage backed securities, to mention a few examples, all had several years of intense investor interest, abnormal returns and portfolio appeal before reverting to more normal ("mean") price levels. Once this occurs, however, there is very little evidence in history that the speculative frenzy that characterized these particular assets reemerge anytime soon, although they usually revert to being traded at normal, risk-adjusted returns. A reasonable expectation, therefore, is that the period of easy money in emerging market stocks is over.

\section{After the Bubble}

In following emerging market "trends," a great many sophisticated fund managers were led to violate the strictest of their own investment rules, something they do with almost predictable regularity. Fund managers have a great deal of money to invest for others, and must meet competitive performance standards to keep it. If they are not invested in this year's fashionable vehicles, their performance may lag during the early phases of investment cycles. Throughout the 1980s, U.S. institutional investors were thought to be responsible for driving high-risk stock and bond prices above reasonable risk-adjusted levels, only to finally secure their positions in time for the market to decline. Professional fund managers have become somewhat used to this, and take their punishment quietly when it comes-because the punishment tends 
to affect many if not most of their rivals in the same way. After major price changes, most fund managers will announce that they are looking for opportunities. This occurred in the case of U.S. junk bonds, mortgage backed securities, REITs, venture capital and other forms of relatively liquid high risk investments, but it has not occurred in the case of large American LBOs or Japanese leveraged investments. With the exception of bottom-fishing in specific "oversold" issues, it is probable that it will not occur in emerging market equities, where the period of abnormal risk-adjusted returns is unlikely to reappear within the next several years. ${ }^{13}$ There are several reasons for this:

First, investors who lost large amounts as well as their confidence in many emerging equity markets are not likely to plunge back in again soon. They will certainly be cautious about investing new money in such markets, and will endeavor to get some of it out. They may exploit special "buying opportunities," but not in large volume. This will show up in a reduced level of transactions in country funds and in emerging market manager-selections by pension funds and other institutional investors. Indeed, it was already appearing in the U.S. during the first three quarters of 1994 when, according to the Securities Industry Association, combined purchases of foreign securities dropped nearly $90 \%$ from a year earlier - to the lowest level in

\footnotetext{
${ }^{13}$ For example, the Mexican stock market reached a low of 1447.52 on the Bolsa index on February 27, 1995 and had by mid-July recovered to about the same level (2231.11) it held on December 20,1994, the day before the initial peso devaluation that set off the crisis. The recovery was mainly due to buying of undervalued shares by local investors, in addition to international funds selectively rebuilding their Mexican portfolio weights and hedge funds trying to take advantage of low share values. Lower U.S. interest rates, lower Mexican inflation rates, and a new Mexican sovereign debt issue may have contributed to market confidence as well. In dollar terms, however, the converted Bolsa index at that point had only recovered from 2231.11 to about 1400 , due to the weakness of the peso.
} 
four years. The decline had been progressive, with the third quarter down $69 \%$ from the second quarter, which in turn was down $43 \%$ from the first quarter of $1994 .{ }^{14}$

Second, investors will be careful not to assume low correlations with the major markets. As an investment class, emerging markets demonstrated a much higher correlation with each other during the early part of 1995 than had been previously experienced. For example, the Mexican crisis clearly spilled-over onto many other emerging equity markets, adversely affecting their performance as well-see Exhibit 5. This demonstrates a substantial erosion of the IPD gains associated with emerging market investments. As inter-market correlations shot up, it was revealed that the eggs being placed in different baskets that were in fact all tied together. This shows up in Exhibit 6 as shift in the efficient frontier downward and to the right (lower returns and higher risk) in the period 1987 (Q4) to 1995 (Q1) is compared with 1987 (Q4) to $1994(\mathrm{Q} 4)$. The risk-return characteristics thus were substantially altered over a period of just three months and triggered by events in only one emerging market country-albeit an important one. Apparently portfolio managers all rushed for the exits, whether or not the local markets were directly related to Mexico, to avoid performance punishment and to anticipate fund redemptions, as well as to maintain their portfolio weights. This may have done lasting damage to the confidence of investors and fund managers in the underlying value of emerging market equities in international portfolio diversification.

Third, investors now appear to realize that there are more risks in securities

\footnotetext{
${ }^{14}$ Securities Industry Association as quoted in The Wall Street Journal, Feb 23, 1995.
} 


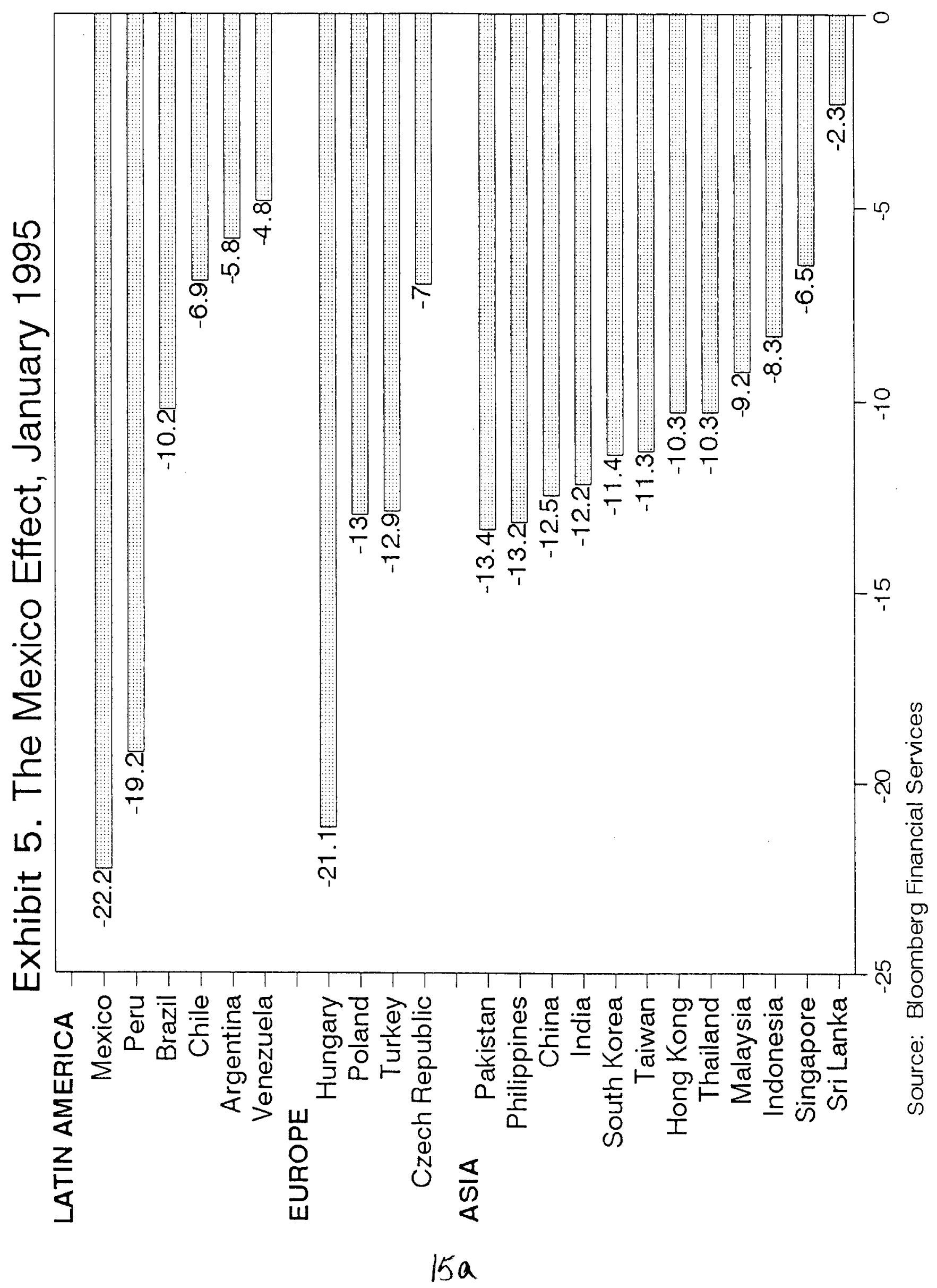




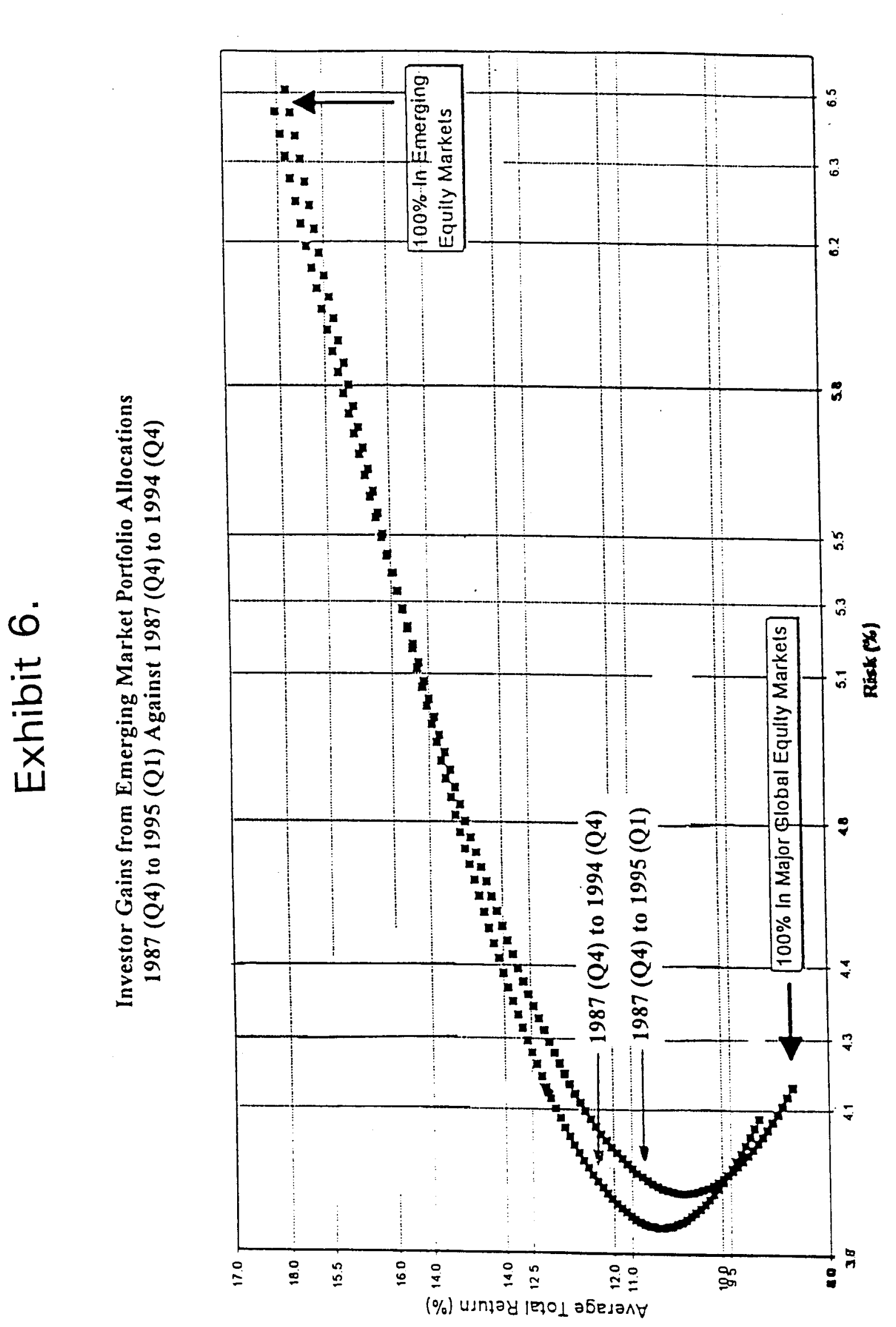

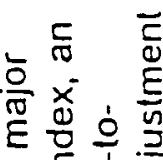

$\Phi \equiv \doteq{ }_{0}^{\prime}$

$\equiv \stackrel{\mathscr{N}}{\mathrm{\sigma}} \stackrel{\mathrm{C}}{\mathrm{C}}$

을응 응

틍

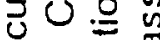

0 ज त

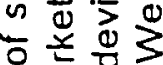

ర $\sum^{\pi}$

ป

을은

ह कٓ

원

ง

어옹

들 $\frac{5}{\mathrm{~s}}$

उ。 $\frac{0}{0}$

ชิ

응

등 훙

응으웜

\凹

उ

次元

$\geq \infty$ 元

ฏ ป

ชั

范

응 뜬

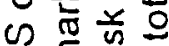

$\supset$ E 뭉

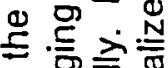

은

드릉

बण ठ

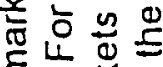

E는 온

일

जू

$\frac{0}{\pi} \equiv$

응 윰

б 흔

은 든

ह 0 i

Q

$\equiv 30$

는후응

خ

爻告

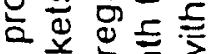

う苋宁

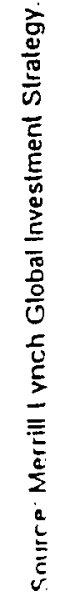


traded in inefficient emerging markets than were originally considered. These include vulnerability to shock-effects from sudden political or economic developments, lack of hedging vehicles to manage risk, and the effect of low-quality information disclosure by companies and governments upon which to base investment decisions. Indeed, disclosed information in many emerging markets is often nearly useless, being late or highly misleading. Auditing and accounting standards are often well below OECD standards, and in many cases few regulations protecting investors' rights exist or are enforced. Accordingly, the best investment information comes from insiders or speculators or those "in the know," which makes these markets much more susceptible to market rigging, fraud and corruption-as one Hong Kong investor was quoted as saying: "Invest in anything where I don't have some kind of inside information? Don't be silly!"

Liquidity in many emerging markets is likewise well below the minimum standards prevailing in developed countries. Often there are virtually no investing institutions, and most shares are owned by individuals or by foreigners. A shortage of supply pushes prices upwards when foreigners are buying, and makes it almost impossible to sell when foreigners are trying to get out. In some countries such as Malaysia, for example, foreigners in 1993 owned more than $50 \%$ of all stocks, and their buying by the end of the year had pushed the value of the stock market capitalization to nearly twice the value of the country's GNP.

Finally, the degree of volatility that investors must tolerate in many emerging markets has been several times greater than in U.S. and other developed-countries' 
markets. For a 60 month period ending in March 1994, for example, the annualized percentage standard deviation of returns in a selection of Latin American countries was $27.99 \%$, and an Asian group $24.18 \%$, as compared to $12.51 \%$ for the U.S. and $19.92 \%$ for the combined European and Japanese markets. Polish returns experienced an average standard deviation of $104.23 \%$, Brazilian $83.21 \% \%$, Argentine $68.00 \%$, Turkish $67.62 \%$ and China, Colombia, Peru, Philippines, Taiwan, Pakistan, Hungary, and Greece had standard deviations greater than $40 \%$ during the same period. ${ }^{15}$

Such high volatilities require the commitment of substantial equity capital by investors - to avoid being wiped out during market declines-substantial patience to wait out the worst of adverse market conditions to finally realize long term gains, and indeed require an expected risk-adjusted total investment return substantially greater than OECD averages just to break even. Although such returns might have been possible for the earliest wave of emerging market investors, they soon evaporated after prices had begun their rapid upward adjustment. However, the earlier one invests in such markets the less one has to base decisions on, and so investing under these circumstances can indeed be compared to a "casino" experience.

The simple lesson for investors in emerging equity markets appears to be that asset allocation to these markets can be justified only when the acquisition price is low enough to provide a margin to cover the true incremental risks, and only when the investor has the ability, the confidence and the patience to ride out the market panics or periods of great illiquidity that occur from time to time. Surely there will be many

\footnotetext{
${ }^{16}$ Data: Bloomberg Financial Services.
} 
investors who will continue to participate actively in these markets, but they will tend to be specialists who are realistic about the prices they are willing to pay. Those who are not specialists will most likely stay away or reduce their existing commitments.

We thus expect that global investors will be much more tough-minded about emerging equity markets in the future. High-performance fund managers will look elsewhere for assets, and emerging-market country funds will continue trading at substantial discounts from their net asset values, to which they have reverted 199495. ${ }^{16}$ Foreign portfolio equity capital will revert to being a scarce commodity in many developing economies, and the term "emerging markets" itself may fade away, its particular time in the colorful lexicon of finance having passed. Countries too, therefore, will have to adjust to new circumstances.

\section{Lessons for Governments}

Like international portfolio investors, governments need to be more realistic about the role of foreign equity capital in their longer-term economic development plans. At least five lessons stand out:

1. Economic reality of attracting capital. Today's economic realities are different from those of a decade ago. There is not much prospect for developmental aid or government-initiated capital formation. Equity capital for development must come from the private sector, both indigenous and foreign investors. Most developing countries still have too little indigenous risk capital, and so must look for what they need

\footnotetext{
${ }^{16}$ On July 4, 1994 the average premium over net asset value of 32 emerging market mutual funds was $28.4 \%$. A year later, the same funds traded at an average discount of $6.9 \%$ to net asset value. Barron's, price quotations for closed-end funds, July 4, 1994 and June 20, 1995.
} 
abroad. The easy-money conditions of the early nineties are over, so foreign capital must be actively solicited. It must be competed-for on the basis of good, long-term, risk adjusted investment returns. Providing an economic environment that holds out adequate prospects of such returns is the job of governments - a big job that includes many changes and reforms, and one that by no means should be shrugged off with the notion that legislation is planned to take care of this or that. Investors care about what actually happens, not whether legislative bills are passed or not. Nor is there much use complaining about foreign investors serving as self-appointed "judge and jury" of the efficacy of national economic policies. These are real people with hardearned money invested in assets they hope make sense for them, or entrusting others to do so on their behalf-relying on real political and economic analysis by people whose careers are on the line.

2. Building financial infrastructure. Governments that want to attract international portfolio investment must be clear about the priority need to create some basic preconditions for viable capital markets - an obvious point honored as much in the breach than in practice. ${ }^{17}$ Fundamental is a functional financial system that

17 See Ingo Walter "Cross-Border Equity Flows: Tapping Into Global Markets," ASEAN Economic Journal, October 1993. 
embraces a viable banking industry, ${ }^{18}$ insurance and securities industries, ${ }^{19}$ pension and mutual funds. ${ }^{20}$ Governments must enact a sensible securities law in order to provide regulatory and enforcement authority against market fraud and other abuses - many countries have done this in recent years, so that ample precedents are available-rules which should address the principles of fiduciary responsibility, full disclosure, fair markets, surveillance and enforcement, and require that minimum standards for training and certification of fiduciaries and intermediaries be met. ${ }^{21}$ Arguably, banks in some developing countries should be encouraged to develop close relationships with particular companies to improve information flows and monitoring

\footnotetext{
${ }^{18}$ Banks in many emerging market countries are all too often large, subsidized bureaucratic institutions that possess few skills in finance and drive customers to transact in parallel (unofficial) markets. Many are loaded-down with nonperforming loans from state-owned enterprises or large domestic corporate combines deemed "too big to fail." The worst of this debt ultimately will have to be separated from the banking system and put into "bad banks," from which future recoveries might someday be paid. The bad bank in such a country, possibly a subsidiary of the central bank, can "purchase" impaired loans from commercial banks using government bonds. Thus recapitalized and solvent, banks can begin again to develop a viable lending business.

${ }^{19}$ This involves providing a central market place, a trading system that includes rules for price disclosure and settlements, and rules providing for the fitness and capitalization of securities firms dealing with the public. The role of banks in the securities industry must also be determined, as well as the extent to which the participation of qualified foreign firms is to be permitted. Foreign firms (often through joint ventures) can contribute considerably to the training of employees and management of local firms, and to the general professionalism and efficiency of national financial systems.

${ }^{20}$ Some developing countries have also created short-term markets in government securities and commercial paper-in tandem with banking activities - as a competitive alternative borrowers and depositors. Countries like Korea, the Philippines and Colombia have had domestic commercial paper markets in operation for twenty years or more, while Poland has recently created one.

${ }^{21}$ For example, much of the recent distress in the Chinese securities market-particularly that involving the Shanghai bond futures market-have been associated with insufficient regulatory and enforcement powers.
} 
their progress. ${ }^{22}$ Using the German "Hausbank" or Japanese "keiretsu" model, banks can develop a stable of special clients, on whose boards their officers sit and whose business is sufficiently well known to them to permit nurturing and assistance in various areas in addition to effective governance and an informal lender-of-last resort relationship. ${ }^{23}$

3. Overhauling corporations. Governments must attach priority to making corporations fit for public ownership, which requires common financial accounting and auditing standards, a company law, and protection against exploitive concentrations of voting power by insiders. The largest source of shares in many countries will come from the privatization of state-owned enterprises intended to end such firms' operating inefficiencies, raise capital for the government, develop a public shareholder base, and establish a growing, profitable, market-oriented private sector. Some, especially in Latin America and Asia, have enjoyed great success with privatization programs and have used the strong markets of the early 1990 s to float as many issues as possible. ${ }^{24}$

22 Roy C. Smith and Ingo Walter, "Bank-Industry Linkages: Models for Eastern European Economic Restructuring," in Christian de Boissieu (Ed.). The New Europe: Evolving Economic and Financial Systems in East and West (Amsterdam: Kluwer, 1993).

${ }^{23}$ For the pros and cons of different systems of corporate control, see Ingo Walter, The Battle of the Systems: Control of Enterprises in the Global Economy (Kiel: Institut für Weltwirtschaft, 1993).

240thers, such as Russia and the former Czechoslovakia, rushed-through privatization programs in the interest of quick reform, but on a basis that may ultimately prove to be self-defeating. None of the foregoing conditions for public ownership were in place, few of the enterprises were economically viable in their own right-or depended on continued government subsidies or public procurement to continue in business-management was not substantially improved, and the process of ownership-distribution through vouchers was rife with fraud, corruption and racketeering. It is difficult to see how ordinary citizens will benefit from such privatization efforts if left with worthless shares while the valuable ones fall into the hands of the well-connected or corrupt. 
Absent basic conditions for viable public ownership, governments should consider privatization through the sale of assets to corporate buyers, perhaps mostly foreign, who can inject capital, knowhow and management, and contribute to the process of rebuilding the companies. Although there may be some political reasons to restrict foreign direct investment in developing economies, there are no good economic ones. Few sources of economic growth are more assured and quick-acting than direct investment by knowledgeable foreign corporations seeking long-term market opportunities.

4. Limited capital controls. Governments should consider certain techniques of limiting the form of portfolio investment inflows - a recommendation that goes against the grain of the Washington Consensus. Although at December 31, 1993 all emerging equity markets combined represented only about $10 \%$ of global stock market capitalization, the effect of portfolio equity inflows on many countries has often been a glut of foreign exchange and liquidity, which can have severely adverse effects. Principal among these is inflationary pressure-caused by a sudden, substantial increase in the money supply - and appreciation of real exchange rates. Imports in some countries subjected to such inflows consequently increased, exports declined, and trade balances deteriorated. In some cases, like Mexico, foreign exchange reserves and dollar bond issues ("tesebonos") were used aggressively to support the currency, and as this became known savvy insiders began to head for the exits. Few emerging market countries were in a position to cope with such flows in recent years, or immune from having sensible policies placed under severe stress. Some 
governments, however, such as Chile, South Africa and several Asian countries, have limited portfolio capital inflows in various ways to avoid the problem of excess liquidity and to maintain a competitive exchange rate. Without such controls, the impact of massive portfolio flows is hard to counteract. ${ }^{25}$

It may also be worth considering whether foreign portfolio equity investments via mutual funds should be tapped using closed-end rather than open-end funds. In closed-end funds, the shock of investor-demand shifts is taken by secondary-market prices of the funds in the developed-country stock markets rather than by massive, destabilizing, cross-border financial flows.

\section{Implications for the Future}

In Paul Krugman's provocative essay on the end of emerging markets ${ }^{26}$ he maintains that the views of the Washington Consensus induced a bubble-like market effect, which ultimately burst-as all bubbles do-leaving developing countries with little to show for it and much confusion as to what policies to pursue in the future. The painful adoption of the virtues of free markets and sound money may now be in doubt by those not finding the expected rewards. Burst by the bubble, the new theory of economic development through self-help and reform may itself now be discredited.

\footnotetext{
${ }^{25}$ In Chile, such controls in effect seek to increase the cost of investment by imposing reserve requirements on loans, stamp taxes on securities transactions, and widening the bands within which the currency can fluctuate.. Of the countries which experienced increased equity market prices in 1994, as against emerging market trends at the time, most maintained restrictions on capital inflows. Vittorio Corbo and Leonardo Hernandez, "Macroeconomic Adjustment to Capital Inflows," World Bank Policy Research Working Paper No. 1377, 1994.

${ }^{28} \mathrm{Op}$. Cit. Supra.
} 
Something new will have to emerge. Krugman does not say what.

Mature observers of previous financial bubbles know that markets do overreact from time to time, especially when new conditions that are not fully understand come into play, and investors respond to revised expectations against current asset prices. These observers know that those who get in early are the ones who make money, but that for them the risks were substantial at the time because no respectable consensus had yet been formed in Washington, New York or anywhere else to make everyone feel comfortable and, indeed to pave the way for many new investors. They also know that the formation of broasd-gauge agreement about such complex and elusive subjects as economic growth in developing countries should be taken with more than a grain of salt. Washington opinion-leaders were responding to the numbers - the money was flowing, so there must be a reason, probably besause the new policies were working at a time when there was no large capital flow into developing sticking to the old, statist policies. The numbers also were responding to the Washington Consensus - the new policies would change the values of securities much more quickly than they would change observed GDP, but what that meant was the likelihood of a large one-time adjustment in values, and one had to get in early to get the benefit of it. And as Krugman points out, one did not want to stand out as a disbeliever in the new, demonstrated results. Now, after the bubble has burst, we are beginning to hear the revisionists tell us how the basic ideas imbedded in the Consensus were wrong.

We do not agree, although it does appear that the basic ideas have occasionally 
been misunderstood as a panacea for most developing-country problems and a form of alchemy for investors. In the long run, the policy changes prescribed by the Washington Consensus are the right ones, but they are difficult to implement and as a result it takes a long time to get real results. Markets will anticipate these results to some extent-they work by discounting future expectations, not remembering the past-but only to some extent. The hard work is in sticking with the free-market policies until they produce some of the expected results. Its a long term process, usually accompanied by some policy backsliding and victimization by world economic events outside the control of individual countries. The new paradigm, if there is one, is to adopt the policies and simultaneously to build the infrastructure necessary for them to provide the greatest value, i.e., to attract foreign capital from a competitive marketplace and to retain it.

Very few emerging market countries have the economic capacity or the political will to adopt far-reaching free-market policies all at once. Who does? Gradual approaches work, however, perhaps best of all. Successfully rebuilt, former developing countries like Japan, Germany, South Korea, Taiwan, Singapore, Spain, Chile at no point adopted a totally free-market approach. They moved purposefully in that direction, but only at a pace that could be accommodated my the accompanying political thinking and infrastructure-building. Other countries that have tried hard to accept the new policies (Mexico, Argentina, Brazil, perhaps India) have had considerable success despite some recent disappointments. They need more time for their efforts to bear the fruit that their more successful peers have enjoyed, but so far 
it appears there is little likehood of a reversion to the pre-Washington Consensus era in any of these countries.

The most powerful part of the new paradigm, however, is that countries must know that it all depends on them. A consistent barometer of their efforts, flawed as it may be from time to time, is in the capital they are able to attract. ${ }^{27}$

While it may be true that foreign capital can be attracted by offering assets for investment at extremely low valuations, that is not the way most countries are going to want to do it. Earning higher valuations will depend on being able to create a credible environment for open market-driven institutions and practices to develop. Some may instead attract investment simply by encouraging GNP growth so that the funds will flow in despite other factors. This appears to be the current Chinese approach. But it will certainly be a fragile one, and regardless of the economy's impressive growth investors are not going to take the country seriously until China changes its basic investment climate. Investors have other places they can go instead. India today may well be one of these. In the end, China may need foreign capital so badly that it will ultimately change its approach.

For now, global equity investors have retreated from emerging markets after price collapses shattered what may have been excessive confidence in their near term future. From now on, money may be harder to come by, but it will still be available to

\footnotetext{
${ }^{27}$ It also depends on where a country is starting from-how much market infrastructure already exists. In Eastern Europe, very little existed and without it large institutional change has been almost impossible to undertake despite some promising signs of entrepreneurial development. Even so, major differences exist between the available infrastructure in the Czech Republic and Russia, between Poland and East Germany, and between countries within this region and China.
} 
those developing countries which follow basic economic strategies consistent with long-term growth and build sound and durable domestic financial infrastructures. Countries want to attract long term, patient investors who are interested in harvesting suitable risk-adjusted returns as a reward for careful selection of countries, industries and companies - and bearing the risks over substantial periods of time.

Governments of emerging market countries have to face reality. To attract capital one has to compete for it in a world market that offers many opportunities to those with funds to invest. To compete successfully, countries have to do what is good for themselves in the long run, yet often difficult and politically controversial in the short-run. They have to fully adopt market economics, satisfy a number of preconditions and then rebuild or build de novo the banking and nonbanking financial institutions that are the core of a workable financial marketplace. Governments must also resolve important issues related to the public ownership of private sector companies and make a credible and sustained commitment to privatization. There are precedents in developing countries that make these steps easier to take, and many sources of aid and technical assistance for those seeking to move in these directions. It usually takes years for these measures to be accomplished in full, but as progress becomes visible and selected gains appear in the interim, so will rekindled interest by global equity investors.

The Washington Consensus, properly adapted, is hardly dead as a set of guideposts for policy from the perspective of the international investor, who see economic stability as a precondition for making asset selections at prices that actually 
mean something based on economic fundamentals and underlying investment values. This hardly means that punters and bottom-fishers can't make plenty of money in chaotic markets shocked by irresponsible public policies. They have in the past and they will again. Nor does it mean that there is a foolproof association between the Washington Consensus criteria and actual economic performance. But the big international money in the end wants to avoid casinos, and governments should understand that the investors' interests in allocating capital on the basis of long-term economic performance of countries, industries and companies should not be too different from their own. 